\title{
THE IMPORTANCE OF THE ARCHIVES OF VENICE, BOLOGNA AND MODENA FOR THE CRIMEAN STUDIES*
}

\author{
FIRAT YAŞA \\ History Department, Faculty of Arts and Sciences, Sakarya University \\ 54187 Serdivan/Sakarya, Turkey \\ e-mail: yasafirat@gmail.com
}

This paper deals with the material of Italian archives related to the history of Crimea. It demonstrates that only a few scholars have dedicated their research to Crimean studies and published papers in Turkey or elsewhere in recent years. Turkish historians have tended mainly to focus on the Ottoman Empire. Although some publications about the Crimean Khanate have been produced in historical literature during the last twenty years, the sources they use are mostly limited to either Russian or Ottoman archives. Italian archives are usually disregarded despite being important sources for historians interested in the Crimea. My aim is to guide researchers who wish to study this subject using Italian archives. First, information about archive catalogues directly connected to relations between the Khanate and the Italian city-states, such as Bologna, Modena and Venice is given. Then some examples of the documents, including letters, dispacci, reports and missionary records, considered to be relevant to the Crimean Khanate, will be presented.

Key words: Crimean Khanate, Venice, Bologna, Modena, letters, reports.

\section{Introduction}

It is generally acknowledged that at the time of the establishment of the Crimean Khanate, Italian City States had a large commercial network in the Crimean Peninsula. Genoese and Venetians especially played an active role in the trade of this territory. Since the beginning of the Khanate's history they were not only engaged in trade, but they also supplied necessary intelligence to their own countries. Initially, the Byzantine Emperor Alexius Comnenus gave some privileges to the Venetians who

* I would like to express my gratitude to Professor Maria Pia Pedani, without whose help this paper could not have been prepared. When I came to Venice for my $\mathrm{PhD}$ dissertation research in 2015, she supported my research, sharing with me her profound experience in archival matters. 
lived in Constantinople. According to the 1265 privilege (officially ratified in 1268), Venetians had a representative with the title of bailo. Therefore, Venetians not only had a privileged position as far as the foreign communities living in Constantinople were concerned, but also had an imperial decree that secured the life and property of the Venetians (Hanß 2013, p. 37; Spuler 1986, p. 1008). The Venetian community also had its own quarter during the Byzantine period: its last existing building was the Balkapanı Han near Rüstem Paşa Mosque that was built on the site of the ancient Venetian Sant'Achidino church (Ağır 2009). Their privileged position did not change after the conquest of Constantinople by Mehmed II in 1453; moreover, in the 1500s the bailos began to live regularly in Pera where they rented a palace, now called the Venedik Saray1, which has long served as the Istanbul residence for the Italian ambassadors, then consul generals (Concina 1995, p. 111; Pedani 2013a). The bailo became one of the most influential foreign diplomats in the Ottoman Empire. His authority was established and extended over and over again by the agreements (ahidname) signed between Ottomans and Venetians after a war or whenever a new sultan ascended the throne: the first one was signed in 1390 and the last one in $1733 .{ }^{1}$ Whenever the bailo came back to Venice, he had to deliver, in front of the Senate of the Republic, a comprehensive report (relazione) about the results of his diplomatic mission (Afyoncu 2012, p. 16; Bertele 2012, p. 9). By doing so, the diplomats followed the law established in 1268 that all Venetian diplomats had to deliver both a speech and a written text on termination of their missions and in 1524 the same law was applied also to every Venetian public official in the subjected lands (Pedani 2009, p. 487).

Venetian merchants carried mainly processed goods such as woolen and silk cloths, paper, copper, tin and glassware from their own country to Istanbul while they imported raw products such as cereals, spice, raw silk, cotton, leather-fur, wax and cannabis (Turan 1968, p. 254; Arbel 1995, p. 16; Mack 2002, p. 20). Thanks to the developing trade relations between Venice and Istanbul, intelligence networks expanded and the bailo played an active role in sending intelligence reports to the Republic of Venice (Dursteler 2002, p. 3). These reports comprised important cases and intelligence relevant to the Ottoman Empire as well as the Crimean Khanate.

The main objective of this study is to explain how to use Italian archival documents as a source for writing the history of the Crimean Khanate. In addition, information will be provided about the kinds of documents that are available in various

\footnotetext{
${ }^{1}$ See the agreements between the Ottoman Empire and Venice: 21 May 1390: Murad I; January-February 1403: Süleyman Çelebi; 30 March 1406: Süleyman Çelebi; 12 August 1411: Musa Çelebi; 6 November 1419: Mehmed I; 4 September 1430: Murad II; 23 February 1446: Mehmed II; 10 September 1451: Mehmed II; 18 April 1454: Mehmed II; 25 January 1479: Mehmed II; 12 January 1482: Bayezid II; 14 (25) December 1502: Bayezid II; 17 October 1513: Selim I; 19 August16 September 1517: Selim I; 1 (17) December 1521: Süleyman I; 2 October 1540: Süleyman I; 25 June 1567: Selim II; 7 March 1573: Selim II; 8-17 August 1575: Murad III; 4-13 December 1595: Mehmed III; 14-22 November 1604: Ahmed I; 8-17 January 1619: Osman II; 19-28 April 1625: Murad IV; 24 January-2 February 1641: Ibrahim I; 12-21 May 1670: Mehmed IV; 26 January 1699: Mustafa II; 9-18 April 1701: Mustafa II; 13-22 June 1706: Ahmed III; 21 July 1718: Ahmed III; 15 May 1733: Mahmud I (sürekli sulh). - Cf. Turan (2000, pp. 598-600); Pedani (2011, pp. 177-178).
} 
Italian archives to support the study of Crimean political, social, economic and cultural history.

\section{Archivio di Stato di Venezia}

The Venice State Archives keep different kinds of archival series which have digital catalogues and are also sometimes available in digital format. ${ }^{2}$ The relations between the city of Venice and the peoples who lived in Crimea began in the Middle Ages. The Venetians had an important colony in Caffa (today Feodosia) and their merchants used to go there to trade as did the Genoese (Karpov 2000, pp. 257-272; see also Karpov 2001). They signed commercial agreements with the khans of the Golden Horde before the Crimean Khanate was established in the middle of the 15th century. The Khans Özbek (1313-1341), Janibek (1341-1357) and Berdibek (1357-1359) issued yarlıks for Venice in 1332, 1342, 1347 and 1358. The Bey of Sudak, Ramadan, wrote letters to the Doge in 1356, while Kutluğ-Timur Beg gave instructions for the Venetian merchants in 1358. Also Taydula khatun, Janibek's wife, wrote to Venice to settle a business affair in 1359 (Thomas - Predelli 1880-1899, Vol. 1, Nos 125, 135, 139, 167; Vol. 2, Nos 14-15, 24-28). The Latin translations ${ }^{3}$ of the letters and decrees issued by these rulers were kept among the most important documents of Venice in the chancellery series of Pacta, Commemoriali and Liber Albus.

After the Crimean Khanate was created in the middle of the 15th century, most Venetian information concerning the Khanate derived from the city-state's diplomats living in the Ottoman Empire. Thus a scholar interested in this subject must first look at the documents produced by Venetian ambassadors and bailos in Constantinople, above all the records named Collegio, Relazioni and Senato, Dispacci ambasciatori, Costantinopoli (ASVe BC; ASVe SDC). The relazioni provide one of the best-known sources for researchers in the Venetian Archives. Although the earliest relazione from Constantinople is dated to 1496, Venetian ambassadors' reports can be traced back to 1268 (Dursteler 2001, pp. 237-238). Now some of them are also available on the web (e.g. Alberi 1840; 1863; Barozzi-Berchet 1871; Firpo 1984; Pedani 1996; Sanudo 1879-1903; Andreas 1914).

The bailo had many and various duties in Istanbul. He was not only interested in gaining information about the Ottoman Empire and its army, but was also charged with solving Venetian merchants' problems. Furthermore, he was sometimes in contact with Ottoman viziers and other officials (Afyoncu 2012, p. 13). Hence, the reports these officials wrote at the end of their missions, together with the letters they sent to Venice from Istanbul yield important information to researchers about almost every subject related to the Ottomans, such as the sultans and the imperial family, economy, military and religious structure of the empire and everyday life in Istanbul. In addition, in these sources hints concerning the Crimean Khanate can also be found when

\footnotetext{
${ }^{2}$ Cf. Guida Generale degli Archivi di Stato Italiani. Roma, 1994.

${ }^{3}$ Latin was the language of the Venetian chancellery in the Middle Ages.
} 
relevant happenings occurred in that region or when the khan was involved in political affairs with Ottoman authorities.

Here is an example from the bailo Giovanni Correr's relazione:

"Hora a questo bisogno suppliscono per eccellenza i Tartari, perché se ne vanno essi alla caccia d'uomini nella giurisdizione di Polonia, di Moscovita, et spesso anco fra Circassi; poi riducono la preda al Caffa, dove sono compri da mercanti et condotti a Constantinopoli" (Pedani 1996, p. 234).

That is to say:

In ancient times Crimean Tatars were famous for slave raiding. They generally went to raid Poland, Muscovy and Circassia and they captured men, women and children. They brought their booty to the Caffa slave market where merchants bought these slaves and took them to Istanbul.

Tomaso Tarsia's report also deals at length with the Tatar khan's behaviour during and after the siege of Vienna in 1683. This Venetian interpreter was present in the Turkish camp and was an eye-witness of the events he described. He notes that the khan suggested to Kara Mustafa pasha to abandon the siege in advance. Therefore, after the battle, the great vizier wanted to have him in his hands probably to kill him as he had done with other Ottoman officials; for this reason the khan fled as soon as possible while Kara Mustafa put another men in his place (Pedani 1996, pp. 684-755).

Another important source for researchers are letters (dispacci), sent by the Venetian ambassadors, the bailos included, to the Senate and other offices. The heads of the Istanbul mission used to report four or even eight times every month. Most of the surviving letters date from the 1560s (Carbone 1974, pp. 11-50; Gürkan 2013, p. 24). The dispacci give a wider and deeper insight into the Ottoman Empire than the relazioni. In this source the Tatar Khans are quoted usually if they received some distinguished honour from the Ottoman sultan, as happened for instance in 1613 when the sultan gave him a jewelled sword and a golden dress (ASVe SDC, Filza 74, 1613, 30 gen./2). Another remark concerning the Crimean Tatars derives from the year 1609 and was made by the bailo Simone Contarini. A nobleman from Poland, as the ambassador describes, arrived in Istanbul in order to complain about the Crimean Tatars because of their invasion of the Polish settlements. This nobleman gave information about the invasion and looked for help from the Ottoman sultan. Bailo Contarini followed the progress of this story and wrote about it in detail in his letters (ASVe SDC, Filza 67, cc. 119, 233, 237, 347).

As mentioned, Venetian diplomats wrote not only to the Senate, but also to other offices, such as the Consiglio di Dieci, the Inquisitori di Stato that looked after the security of the state and the Cinque Savi alla Mercanzia that controlled trade. In the archives of these institutions it is also possible to find documents about the Ottoman Empire. We must not forget the papers produced in Istanbul by the bailo's chancellery either which are now kept in Venice in the series Archivio del bailo a Costan- 
tinopoli (Pedani 2013b, pp. 381-404). Let us give an example of the news that can be found in this source: on 25 June 1636, the Venetian chancellery discussed the affair of a Tatar who said that a slave girl named Anusa, now in Venetian hands, had been stolen from his properties in Kaffa (ASVe BC, Busta 285, ad annum).

Besides the records of the diplomats sent to Istanbul, there are also other reports written by diplomats sent to the Persian rulers. One of these was Giosafat Barbaro (1413-1494) (Almagià 1964), a Venetian merchant who lived for a long period in Tanais and knew the Crimean Tatar language. In his report he recalls an episode when he lived in Venice in 1455. While walking in the Rialto market he saw two Tatar slaves and began to talk with them in their language. He realised that they were being kept in chains unlawfully since they were free men and he succeeded in procuring their freedom. Afterwards, he took them to his house and, as they walked along, they talked together. At a certain point Barbaro recognised one of the two: he was a customs officer he had met many times in Tanais. Barbaro quoted the city and the name Yusuf which he used there and the Tatar immediately felt down on his knees and said: "This is the second time you have saved my life. The first was when there was the great fire in Tanais and you made a hole in the wall so that we were able to make our way to safety." Then, Barbaro helped them to return home. He ends the story saying (Lockhart-Morozzo-Tiepolo 1973, pp. 88-89):

"Sichè niuno mai deve partendose da altri (con l'opinion de non ritornar mai più in quelle parte) dimenticarse de le amicitie, como che se mai più se havesseno a veder insieme. Possono accader mille cose che se haverano a veder assieme, et forsi colui che più po' harà ad haver bisogno de cholui che mancho po'."

Thus, when taking leave of others (thinking that he will never return to that place) no-one should ever forget his friend on the grounds that they will never see one another again. One thousand things may happen to bring these two people together again and perhaps the more powerful one may need the help of the weaker.

\section{Biblioteca Universitaria di Bologna}

The Bologna University library keeps the papers and books of Luigi Ferdinando Marsili (1658-1729), an Italian diplomat who knew Turkish very well and worked for the Habsburgs (Gullino - Preti 2008). In Marsili's archive valuable pieces of information can be found not only about the Crimean Khanate, but also about the Black Sea region. ${ }^{4}$ The first selected document in the catalogue is a manuscript map of 16th century Crimea drawn by an unknown person. The legend gives the names of some towns and, among others, contains the following words: ... / Bacgie Serai Rezidenza del Tartar kham / CRIMEA / Che contiene 10.000 villaggi il più grande de quali havrà

\footnotetext{
${ }^{4}$ For the catalogue of the archive, see Marsili.
} 


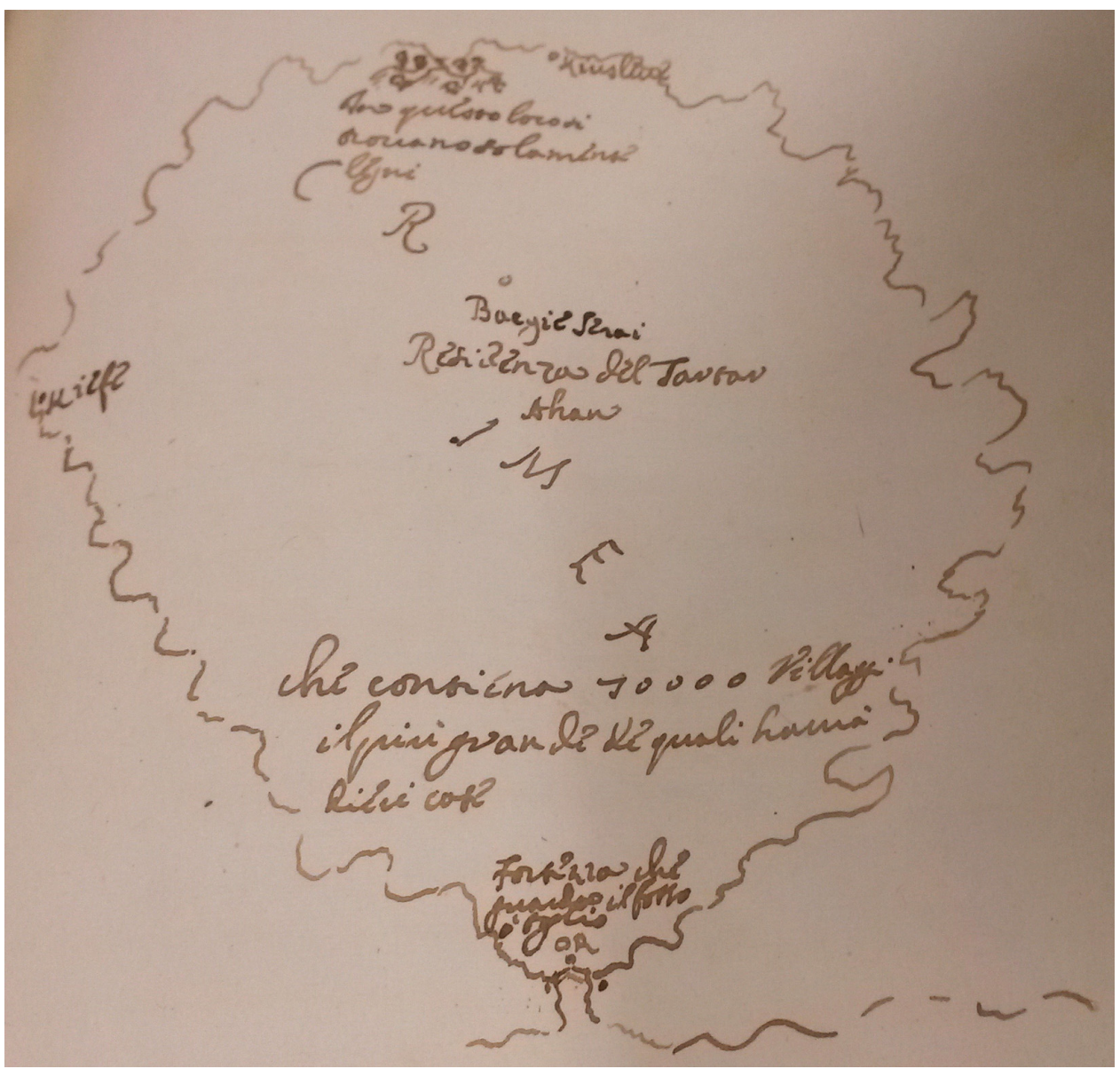

Figure 1. A Crimean peninsula map in the 16 th century

dieci case / Fortezza che guarda il fosso ... (Marsili, p. 153), that is to say: “... Bakhchysarai the place where the Tatar khan lives / Crimea / There are 10,000 villages in the peninsula and the biggest one has about ten houses / Stronghold that controls the ditch ..."

Another document in the catalogue is a genealogical tree. It starts with the name of Genghis Khan (1206-1227), and it goes on with the names of rulers of the Golden Horde but with a lot of omissions: there are Kusti (?), Berke (1257-1266), Mengu-Timur (1266-1280), Casas (?), Belbuka (?), Erne (?), Okuz (?), Tamurlane (?), Timur-Malik (1377-1378), Emir (Amir Pulat?) (1364-1365), Bareb (?), Tokhtamysh (1378-1397), Mehemet Parvus (Küçük Muhammad 1435-1459) and Qaadeer Berdi (1419) (Marsili, p. 288). It gives a striking example of the scanty knowledge of the Europeans about the Tatars in the Middle Ages. 


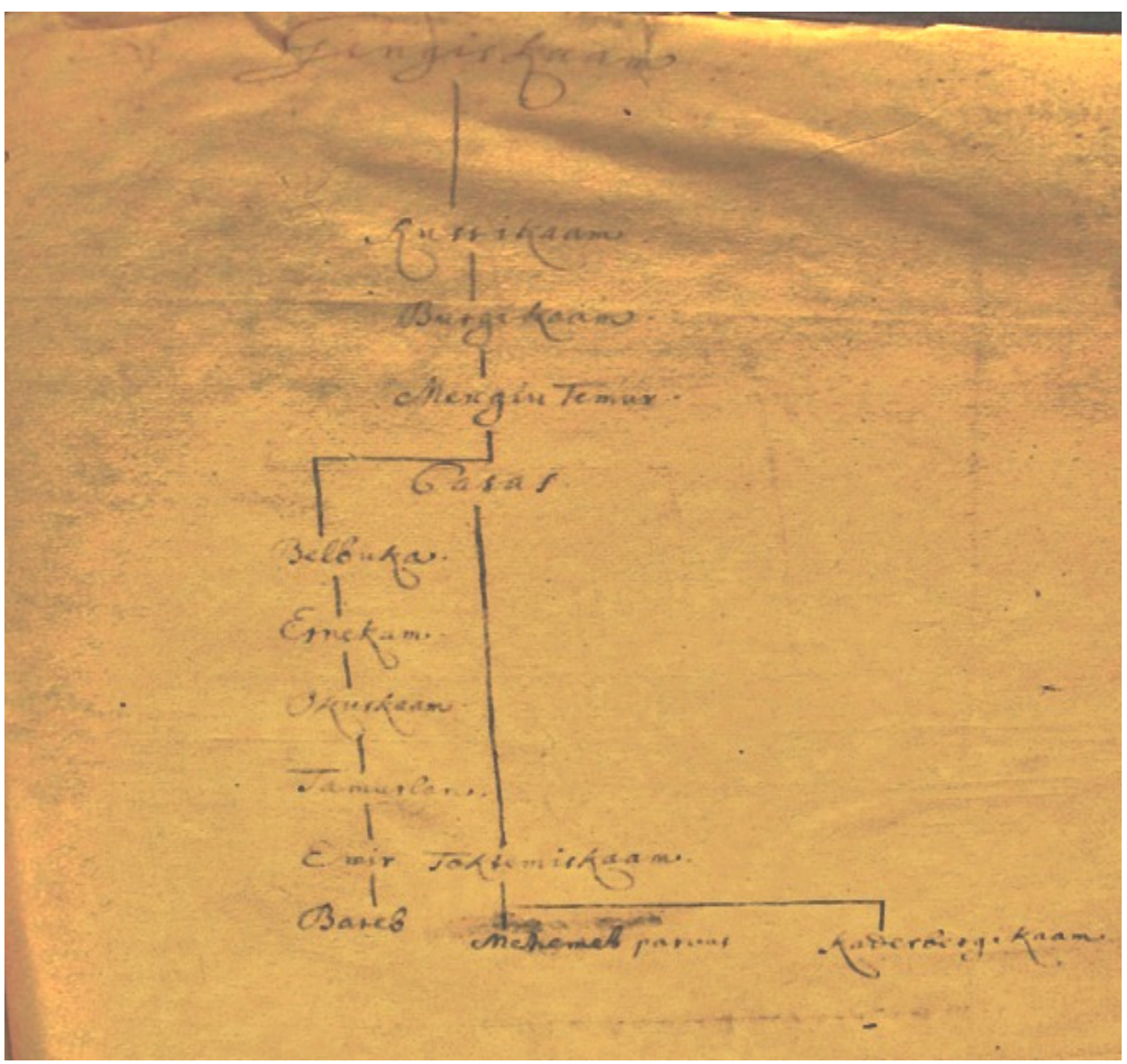

Figure 2. The Tatar khans' genealogical tree

\section{Archivio di Stato di Modena}

The Modena Archive is very rich in documents related to Crimea. ${ }^{5}$ Researchers have to look for the catalogue of the archives (CSCI ASM). Among the most important collections one can find documents about the warfare between Crimea and Poland in 1650, letters written by a Dominican missionary, and a general description of the Crimean peninsula in 1582. For the purpose of this study we would like to focus on two documents: the first is a report that explains the causes of the Crimean Khan Mehmed Giray's death in 1584 .

\footnotetext{
${ }^{5}$ For the Modena Archives, see Özkan (2004).
} 
The report begins with a short summary of what it deals with:

"Compendio delle cose seguite l'anno 1584 et li due anni inanti in Taurica con le cause della morte de Machomete, Prencippe de Tartari Precopensi. Regnava questi anni passati nella sede della Tartaria Precopense con titolo di Cesar che appresso quella gente come appresso de Moscoviti significa imperator Machomete Chereio prencipe che nella eta sua giovane s'era mostrato soldato valoroso e praticissimo dell'arte militare, ma da poi cresciuti gli anni et facendosi grave di corpo, cominciò ad abhorire la guerra et massime la guerra straniera et lontana, tanto più trovandosi pieno di varij sospetti nella casa propria, havendosi dato a credere che li fratelli suoi medesimi pensassero di carciarlo di stato et che gli animi de paesani inclinassero alla rebellione in favor loro" (CSCI ASM, Busta 193, Specie Unica).

That is to say:

Summary of the things that happened during the year 1584 and in the two previous years in the Taurica region together with the reasons for the death of Mehmed, Prince of the Crimean (Precopensi) Tatars. In the past years the prince Mehmed Geray (Machomete Chereio) ruled the Crimean Tatar land (Tartaria Precopense) with the title of Khan (Cesar) that means emperor for that people as well as for the Russians (Moscoviti). In his youth, he had proved his worth as a soldier and his skill in the military art, but later, with the passage of time he became fat and began to detest war, especially every foreign war in distant lands. This behaviour was caused especially by the fact that he nourished various suspicions against the members of his own house, and that he believed that his own brothers were thinking of banishing him from his state and that his subjects' minds were ready to rebel in their favour.

The second document, which is written in Latin and is composed of two pages, is very important for the history of diplomatic relations. This letter was sent from the Crimean Khan Janibek Giray to the King of Sweden on 2 December 1631. It is not the first letter exchanged between the two states, but it offers interesting clues to understand the diplomatic relations of that period.

In 1630 Janibek Giray sent an envoy to the Swedish King Gustav Adolf (Święcicka 2005, pp. 49-62). As a response, in the following year, Gustav Adolf sent one of his noblemen, called Baron Benjamin, to Crimea to look for military support against his enemies. During the trip the Swedish envoy got sick, and was obliged to remain for approximately one year in Bakhchysarai, which was the capital city of the Crimean Khanate (Porshnev 1995, p. 131). In exchange, Janibek Giray sent Kamber Ağa, a faithful nobleman, to the king in order to negotiate friendly terms with him. Afterwards, he sent also other envoys, such as Musa and Nur Ali Oğlan. Crimean Tatars could not help Gustav Adolf as is clearly stated in this letter. Janibek Giray, however, 
did not lose the opportunity of flattering the king and, at the same time, of showing his own goodwill as far as Sweden was concerned:

In your name the envoy orally expounded that, if during the armistice the King of Poland gives back his soul to his Creator and the news of his death reaches our ears, we shall send our envoys to the senate of Poland to the effect that, if they want everlasting friendship and brotherhood with us, they should elect no other person as their king but you, since we see nobody else more worthy of such a crown than you. ${ }^{6}$

\title{
Conclusion
}

The aim of this paper was to call attention and give a short introduction to the sources to be found in various Italian archives concerning the Crimean Khanate. It gives only a brief but hopefully illuminating glimpse of some of the documents that are to be found in Venice, Bologna and Modena. In this field of research Italian archives are no less important than the Ottoman and Russian archives, and sometimes they can even surprise the researchers with the high quality of the information they provide.

\begin{abstract}
Abbreviations
$\mathrm{ASVe}=$ Archivio di Stato di Venezia

ASVe BC = Archivio di Stato di Venezia, Archivio del bailo a Costantinopoli, Busta. 285, ad annum.

ASVe SDC $=$ Archivio di Stato di Venezia, Senato, Dispacci degli ambasciatori e residenti, Costantinopoli, Filza 67, Filza 74.

CSCI ASM = Corteggi e documenti di Stati e Città Italia, Archivio di Stato di Modena.

Marsili = Biblioteca Universitaria di Bologna, Catalogo dei manoscritti di Luigi Ferdinando Marsili, Conservati nella Biblioteca Universitaria di Bologna, Lodovico Frati, Vol. 27.
\end{abstract}

\section{References}

Afyoncu, E. (2012): Balyos Raporları ve Osmanlı Tarihi. In: Afyoncu, Erhan (ed.): Venedik Elçilerinin Raporlarına Göre Kanunî ve Pargalı İbrahim Paşa. Translated by Pınar GökparElettra Ercolino. Istanbul, Yeditepe Yayınları, pp. 11-34.

Ağır, A. (2009): İstanbul'un Eski Venedik Yerleşimi ve Dönüşümü. İstanbul, İstanbul Araştırmaları Enstitüsü.

6 "Pro interim nomine tuo legatus oretenus nobis exposuit quod si intra hoc induciarum tempus Rex Poloniae suo Creatori spiritum reddet statim atque eius mors ad nostras pervenerit aures ut ad Poloniae senatum nostros legatos mittamus quod si nobiscum perpetuam amicitiam et fraternitatem optent non aliam personam ni eorum Regem eligant quam tuam cum non alium tali corona digniorem quam te videamus" (CSCI ASM, Busta 193, c. 2). 
Almagià, R. (1964): Barbaro, G. In: Treccani, Giovanni (ed.): Dizionario Biografico degli Italiani. Vol. 6. Roma, Istituto dell'Enciclopedia Treccani.

Alberi, E. (1840, 1844, 1855): Le relazioni degli ambasciatori veneti al Senato, serie III, Vol. 1: Firenze, Tipografia all'insegna di Clio, 1840; Vol. 2: Firenze, Tipografia all'insegna di Clio, 1844; Vol. 3: Firenze, Società Editrice Fiorentina, 1855.

Alberi, E. (1863): Le relazioni degli ambasciatori veneti al Senato durante il secolo decimosesto, Appendice, XV. Firenze.

Andreas, W. (1914): Eine unbekannte Venetianische Relation über die Türkei. In: Cavalli Bayllo, Marin di (ed.): Sitzungsberichte der Heidelberger Akademie der Wissenschaften, Phil.-hist. Klasse, pp. 1-13.

Arbel, B. (1995): Trading Nations Jews and Venetians in the Early Eastern Mediterranean. LeidenNew York-Köln, Brill.

Archivio di Stato di Venezia (1994): Guida Generale degli Archivi di Stato Italiani, Vol. 4. Roma.

Barozzi, N. - Berchet, G. (1871): Le relazioni degli stati europei lette al Senato dagli ambasciatori veneziani nel secolo decimosettimo. Turchia, Venezia, P. Naratovich.

Bertele, T. (2012): Venedik ve Kostantiniyye Tarihte Osmanl-Venedik İlişkileri. Translated by Mahmut H. Şakiroğlu. Istanbul, Kitap Yayınevi.

Cancelleria Ducale Estense Estero, Corteggi e documenti di Stati è Città Italia, Stati Varii, Tartaria, Busta 193.

Cancelleria Ducale Estense Estero, Corteggi e documenti di Stati è Città Italia, Stati Varii, Tartaria, Busta 193, Specie Unica.

Carbone, S. (1974): Note introduttive ai dispacci al Senato dei rappresentanti diplomatici veneti. Serie: Costantinopoli, Firenze, Inghilterra, Pietroburgo, Roma, Archivi di Stato.

Concina, E. (1995): Il Doge e Il Sultano Mercarura, arte e relazioni nel primo '500- Doç ve Sultan 16. Yüzyıl Başlarında Ticaret, Sanat ve Illişkiler. Translated by Sema Postacioğlu Banon. Roma, Logart Press.

Dursteler, E. R. (2001): Describing or Distorting the "Turk"?: The Relazioni of the Venetian Ambassadors in Constantinople as Historical Source. Acta Histriae Vol. 19, Nos 1-2, pp. 231 248.

Dursteler, E. R. (2002): The Bailo in Constantinople: Crisis and Career in Venice's Early Modern Diplomatic Corps. Mediterranean Historical Review Vol. 16, No. 2, pp. 1-30.

Ennio C. (1995): Il Doge e Il Sultano Mercarura, arte e relazioni nel primo '500- Doç ve Sultan 16. Yüzyll Başlarında Ticaret. Sanat ve Ilisskiler. Roma, Logart Press.

Firpo, L. (1984): Relazioni di ambasciatori veneti al Senato, Vol. XIII, Costantinopoli (15901793). Torino, Bottega d'Erasmo.

Gullino, G. - Preti, C. (2008): Marsili, L. F. In: Caravale, Mario (ed.): Dizionario Biografico degli Italiani. Vol. 70. Roma, Istituto dell'Enciclopedia Treccani, pp. 771-781.

Gürkan, E. S. (2013): Fonds for the Sultan: How to Use Venetian Sources for Studying Ottoman History? News on the Rialto Vol. 32, pp. 22-28.

Hanß, S. (2013): Baili e ambasciatori - Bayloslar ve Büyükelçiler. In: Pedani, Maria Pia (ed.): Il Palazzo di Venezia a Istanbul e i suoi antichi abitanti - Istanbul'daki Venedik Sarayl ve Eski Yaşayanlart. Venezia, Hilâl (Studi Turchi e Ottomani 3), pp. 35-52.

Karpov, S. P. (2000): La Navigazione Veneziana nel Mar Nero 13. -15. sec. Ravenna, Edizioni del Girasole.

Karpov, S. P. (2001): Venezia e Genova: rivalità e collaborazione a Trebisonda e Tana, secoli XIII$X V$. in Genova, Venezia, il Levante nei secoli XII-XIV (Atti del convegno internazionale di studi, Genova-Venezia, 10-14 Marzo 2000), a cura di G. Ortalli-D. Puncuh, Genova 2001 (= "Atti della Società ligure di storia patria", n. s., XLI/1) Diplomatarium veneto- 
levantinum, edited by George Martin Thomas - Riccardo Predelli, 2 Vols, Venetiis, Deputazione veneta di storia patria, 1880-1899, Vol. 1, Nos 125, 135, 139, 167; Vol. 2, Nos 14$15,24-28$.

Lockhart, L. - Morozzo, R. - Tiepolo, M. F (1973): I viaggi in Persia degli ambasciatori veneti Barbaro e Contarini. Roma, Istituto Poligrafico dello Stato.

Mack, R. E. (2002): Bazaar to Piazza: Islamic Trade and Italian Art, 1300-1600. London, University of California Press.

Özkan, N. (2004): Modena Devlet Arşive’ndeki Osmanlı Devleti'ne Illişkin Belgeler. Ankara, Kültür ve Turizm Bakanlığı.

Pedani, M. P. (1996): Relazioni di ambasciatori veneti al Senato, Vol. XIV, Relazioni inedite. Costantinopoli (1508-1789). Padova, Bottega d'Erasmo.

Pedani, M. P. (2009): Relazione in Encyclopaedia of the Ottoman Empire. Edited by G. Ágoston and B. Masters. New York, NY, Facts on File Library of World History.

Pedani, M. P. (2011): “Osmanlı Padişahının Adına” İstanbul'un Fethinden Girit Savaşı'na Venedik'e Gönderilen Osmanlılar. Ankara, Türk Tarih Kurumu.

Pedani, M. P. (2013a): Il Palazzo di Venezia à Istanbul e $i$ suoi antichi abitanti/Istanbul'daki Venedik Sarayı ve Eski Yaşayanları. Venezia, Edizioni Ca' Foscari.

Pedani, M. P. (2013b): Come (non) fare un inventario d'archivio, Le carte del Bailo a Costantinopoli conservate a Venezia. Mediterranea Ricerche Storiche Vol. 28, pp. 381-404.

Porshnev, B. F. (1995): Muscovy and Sweden in the Thirty Years' War 1630-1635. Edited by Paul Dukes, translated by Brian Pearce. Cambridge University Press.

Sanudo, M. (1879-1903): I diarii. Vol. 58. Venezia.

Spuler, B. (1986): Balyos. In: Gibb, H. A. R. - Kramers, J. H. - Lévi-Provençal, E. - Schacht, J. (eds): The Encyclopaedia of Islam, Vol. 1. Leiden, Brill, p. 1008.

Święcicka, E. (2005): The Collection of Ottoman-Turkish Documents in Sweden. Frontiers of Ottoman Studies Vol. 2, pp. 49-62.

Thomas, G. M.-Predelli, R. (eds) (1880-1899): Diplomatarium veneto-levantinum, 2 vols. Venetiis, Deputazione Veneta di storia patria.

Turan, Ş. (1968): Venedik'te Türk Ticaret Merkezi. Belleten Vol. 32, pp. 247-283.

Turan, Ş. (2000): Türkiye-İtalya İlişkileri, I. Selçuklular'dan Bizans'ın Sona Erişine. Ankara, T.C. Kültür Bakanlığı.

\section{Appendix}

\section{Publishing Relazioni}

\begin{tabular}{|lll|}
\hline 1496 & Alvise Sagundino & Sanudo, I, coll. 397-400 \\
1499 & Andrea Zancani & Sanudo, II, coll. $695-696,699-702$ \\
1500 & Alvise Manenti & Sanudo, III, coll. 179-181 \\
1503 & Andrea Gritti & Alberi, III/3, pp. 1-44 \\
1503 & Zaccaria de' Freschi & Sanudo, V, coll. 26 \\
1503 & Gian Giacomo Caroldo & Sanudo, V, coll. 455-468 \\
1508 & Andrea Foscolo & Pedani, pp. 3-32 \\
1514 & Antonio Giustinian & Alberi, III/3, pp. 45-50 \\
1518 & Alvise Mocenigo & Alberi, III/3, pp. 51-55 \\
1519 & Bartolomeo Contarini & Alberi, III/3, pp. 56-58 \\
1522 & Marco Minio & Alberi, III/3, pp. 69-91 \\
\hline
\end{tabular}




\begin{tabular}{|c|c|c|}
\hline 1522 & Tommaso Contarini & Pedani, pp. 33-39 \\
\hline 1524 & Pietro Zen & Alberi, III/3, pp. 93-97 \\
\hline 1526 & Pietro Bragadin & Alberi, III/3, pp. 99-112 \\
\hline 1527 & Marco Minio & Alberi, III/3, pp. 113-118 \\
\hline 1530 & Pietro Zeno & Alberi, III/3, pp. 119-122 \\
\hline 1530 & Tommaso Mocenigo & Pedani, pp. $41-46$ \\
\hline 1534 & Daniele de' Ludovici & Alberi, III/1, pp. 1-32 \\
\hline 1550 & Alvise Renier & Pedani, pp. 47-86 \\
\hline 1553 & Bernardo Navagero & Alberi, III/1, pp. 33-110 \\
\hline 1553 & Anonimous & Alberi, III/1, pp. 193-270 \\
\hline 1554 & Domenico Trevisan & Alberi, III/1, pp. 111-192 \\
\hline 1557 & Antonio Erizzo & Alberi, III/3, pp. $123-144$ \\
\hline 1558 & Antonio Barbarigo & Alberi, III/3, pp. $145-160$ \\
\hline 1558 & Michiel Nicolò & Pedani, pp. $87-125$ \\
\hline 1560 & Marino Cavalli & Alberi, III/1, pp. 271-298 \\
\hline 1562 & Andrea Dandolo & Alberi, III/3, pp. $161-172$ \\
\hline 1562 & Marcantonio Donini & Alberi, III/3, pp. $173-208$ (for the general public) \\
\hline 1562 & Marcantonio Donini & Pedani, pp. $127-131$ (for the Senate) \\
\hline 1564 & Daniele Barbarigo & Alberi, III/2, pp. $1-59$ \\
\hline 1565 & Alvise Buonrizzo & Alberi, III/2, pp. $61-76$ \\
\hline 1567 & Marino Cavalli & W. Andreas \\
\hline 1570 & Alvise Buonrizzo & Pedani, pp. $133-158$ \\
\hline 1571 & Jacopo Ragazzoni & Alberi, III/2, pp. $77-102$ \\
\hline $1571-1573$ & Anonimous & Pedani, pp. $159-176$ \\
\hline 1573 & Aurelio Santa Croce & Pedani, pp. 177-192 \\
\hline 1573 & Marcantonio Barbaro I & Alberi, III/1, pp. $299-346$ \\
\hline 1573 & Andrea Badoer & Alberi, III/1, pp. $347-368$ \\
\hline 1573 & Costantino Garzoni & Alberi, III/1, pp. $369-436$ \\
\hline 1573 & Marcantonio Barbaro II & Alberi, Appendice, XV, pp. 387-415 \\
\hline 1575 & Anonimous & Alberi, III/2, pp. $309-320$ \\
\hline 1576 & Antonio Tiepolo & Alberi, III/2, pp. 129-191 \\
\hline 1576 & Giacomo Soranzo & Alberi, III/2, pp. 193-207 \\
\hline 1576 & Antelmi Bonifacio & Pedani, pp. 193-199 \\
\hline 1576 & Giacomo Soranzo & Pedani, pp. 201-223 \\
\hline $1577-1581$ & Anonimous & Alberi, III/2, pp. $427-470$ \\
\hline 1578 & Giovanni Correr & Pedani, pp. $225-257$ \\
\hline 1582 & Maffeo Venier & $\begin{array}{l}\text { Alberi, III/1, pp. } 437-468 ; \text { III/2, pp. } 295-307 \\
\text { (with other dates) }\end{array}$ \\
\hline 1583 & Paolo Contarini & Alberi, III/3, pp. $209-250$ \\
\hline \multirow[t]{2}{*}{1582} & G. Soranzo (Livio & \\
\hline & Celini da Foligno) & Alberi, III/2, pp. 209-253 \\
\hline 1584 & Giacomo Soranzo & Pedani, pp. $259-310$ \\
\hline 1585 & Gianfrancesco Morosini & Alberi, III/3, pp. $251-322$ \\
\hline 1590 & Giovanni Moro & Alberi, III/3, pp. $323-380=$ Firpo, pp. $1-58$ \\
\hline 1590 & Lorenzo Bernardo & Pedani, pp. 311-394 \\
\hline 1592 & Lorenzo Bernardo & Firpo, pp. 59-166 \\
\hline 1592 & Lorenzo Bernardo & Firpo, pp. $167-242$ \\
\hline 1594 & Matteo Zane & Alberi, III/3, pp. $381-444=$ Firpo, pp. $243-308$ \\
\hline
\end{tabular}




\begin{tabular}{|c|c|c|}
\hline 1595 & Girolamo Cappello & Pedani, pp. 395-474 \\
\hline 1596 & Leonardo Donà & Firpo, pp. 309-370 \\
\hline 1603 & Agostino Nani & Barozzi-Berchet, I/1, pp. $11-44=$ Firpo, pp. $371-406$ \\
\hline 1608 & $\begin{array}{l}\text { O.Bon, description of } \\
\text { Topkapi }\end{array}$ & Barozzi - Berchet, I/1, pp. 59-124 = Firpo, pp. $407-472$ \\
\hline 1609 & Ottaviano Bon & Pedani, pp. $475-523$ \\
\hline 1612 & Simone Contarini & Barozzi - Berchet, I/1, pp. $125-254=$ Firpo, pp. $473-602$ \\
\hline 1616 & Cristoforo Valier & Barozzi - Berchet, I/1, pp. $255-320=$ Firpo, pp. $603-668$ \\
\hline 1627 & Giorgio Giustinian & Pedani, pp. $525-633$ \\
\hline 1634 & Giovanni Cappello & Barozzi - Berchet, I/2, pp. $5-68=$ Firpo, pp. $669-735$ \\
\hline 1637 & Pietro Foscarini & Barozzi - Berchet, I/2, pp. $69-104=$ Firpo pp. $737-771$ \\
\hline 1637 & Anonimous & Pedani, pp. $635-683$ \\
\hline 1641 & Alvise Contarini & Barozzi - Berchet, I/1, pp. $321-434=$ Firpo, pp. $773-888$ \\
\hline 1641 & Pietro Foscarini & Barozzi - Berchet, I/2, pp. $105-120=$ Firpo, pp. $889-906$ \\
\hline 1676 & Giacomo Querini & Barozzi - Berchet, I/2, pp. $121-196=$ Firpo, pp. $907-981$ \\
\hline 1680 & Giovanni Morosini & Barozzi - Berchet, I/2, pp. $197-248=$ Firpo, pp. $983-1034$ \\
\hline 1682 & Pietro Civran & Barozzi-Berchet, I/2, pp. 249-286 = Firpo, pp. $1035-1071$ \\
\hline 1683 & Tommaso Tarsia & Pedani, pp. $685-755$ \\
\hline 1684 & Giambattista Donà & Barozzi-Berchet, I/2, pp. $287-351=$ Firpo, pp. $1073-1137$ \\
\hline 1706 & Carlo Ruzzini & Pedani, pp. $757-824$ \\
\hline 1724 & Girolamo Vignola & Pedani, pp. $825-881$ \\
\hline 1727 & Francesco Gritti & Pedani, pp. $883-948$ \\
\hline 1746 & Giovanni Donà & Pedani, pp. 949-972 \\
\hline 1782 & Andrea Memmo & Pedani, pp. $973-1026$ \\
\hline 1786 & Agostino Garzoni & Pedani, pp. $1027-1037$ \\
\hline 1789 & Girolamo Zulian & Pedani, pp. $1039-1055$ \\
\hline 1793 & Nicolò Foscarini & Firpo, pp. 1139-1152 \\
\hline
\end{tabular}

